\title{
Global economic transformation in modern conditions: problems and challenges
}

\author{
Kheda Murtazova ${ }^{1}$, and Kisa Ibragimova ${ }^{2}$ \\ ${ }^{1}$ Chechen State University, 364024 Grozny, Russian Federation \\ ${ }^{2}$ Grozny State Oil Technical University named after Academician M.D. Millionshchikova, 364061 \\ Grozny, Russian Federation
}

\begin{abstract}
The development of the global economy has led to the fact that humanity has repeatedly faced complex problems that have a significant impact on the mechanism of the world economy. These problems fully manifested themselves in the 60-70s of the XX century and were called global. The development of the modern global economy makes adjustments to the priority of global problems. At the same time, the set of global problems is constantly changing. Old global problems acquire new content and understanding, along with the emergence of completely new global problems. The limited financial capacity of mankind to solve global problems requires political solutions and the establishment of effective international cooperation.
\end{abstract}

\section{Introduction}

The global problems of our time are a set of the most acute world problems generated by the uneven development of different areas of life of modern mankind and the deepening disagreements between man and nature, contradictions in relations between people [1]. The social progress of mankind and the further existence of civilization depend on the solution of global problems. All global problems facing humanity can be divided into four main groups: political, economic, environmental, and social (figure 1). 


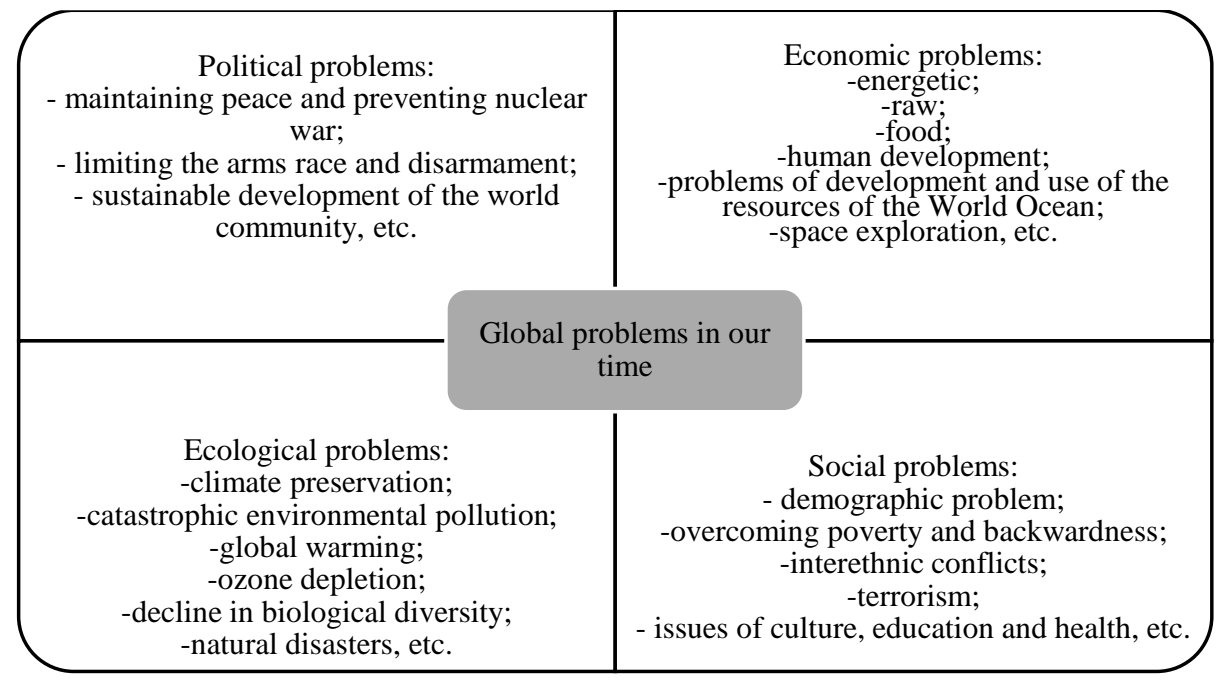

Fig. 1. Global problems of our time

The food problem accompanies humanity throughout its history and occupies a special place among the global problems of our time [2]. With its aggravation, the food problem not only disrupts the normal functioning of the mechanism of the world economy, but threatens the very existence of mankind. Food satisfies the primary needs of the population, therefore food shortages are regarded as a disaster requiring a quick response. The global food problem is multifaceted and, in addition to the immediate problem of hunger and malnutrition, implies such aspects as: the quality and structure of nutrition; the state of health of the population; food supplies and their shortages; uneven distribution of food; different levels of consumption and needs of the population; high food prices [3]. The world food system is currently characterized by the following main trends: maintaining a high level and volatility of food prices, leading to the insecurity of a huge part of the population with food; strengthening price regulation and restricting exports in order to reduce prices in the domestic market; accelerated growth in demand for food, including in countries such as China, India, Thailand, Malaysia, etc .; an increase in the area under crops for biofuel production; reduced investment in global agriculture; the growing increase in the incidence of hunger in the world, as of 2013, 842 million people are undernourished in the world, the vast majority of whom are the population of developing countries. The population of the planet, according to scientists' forecasts, by 2025 will increase to 8.5 billion people, $83 \%$ of whom will live in developing countries [5]. However, the question of the possibility of meeting the needs of the population for food from the available resources at the current level of technology development remains unresolved. The main factors in solving the global food problem are the following: an increase in the volume of food production, associated, among other things, with the implementation of projects of reserve areas for agricultural development; agricultural intensification; application of advanced agricultural methods together with traditional ones; implementation of environmental protection measures; diversification of the economic structure of developing countries; abandoning the idea of self-sufficiency in food and meeting the growing needs for food products at the expense of income from the export of products of other industries; attraction of developing countries to scientific and technological achievements of agriculture [4].

As part of the pre-forecast stage of research, a methodological scheme has been developed that makes it possible to fully take into account the results of the actions of international actors on the processes of transformation of the global economy. 
The key aspects of such a methodological scheme are universal paradigmatic tools for analyzing and synthesizing the concepts used.

\section{Formation of a spectrum of new geopolitical conditions}

S. Cohen's concept of regional geopolitics is based on a hierarchical principle. According to Cohen, it is the United States and Europe that form the global geopolitical balance, and the countries of Africa and Latin America act as a constant source of problems and instability [6]. In addition, S. Cohen substantiated the idea of the dominance of highly developed countries, which leads to the formation of the concept of a "unipolar world", the centers of which are the United States, Europe and Japan, which have the same political system, highly developed economy and interests that exclude their war against each other [7] Simultaneously, S. Cohen put forward the idea of "defense consciousness" of the United States and a statement of the fact that regionalization in the world economy leads to the loss of US geopolitical dominance.

In this connection, America is showing a restrained attitude towards the European Union, which has formed as a confederation and is positioning itself as an emerging potential superpower with a single currency, the euro, which is already fiercely competing with the dollar, previously the only world currency. Therefore, American geopolitics, taking into account the new realities, weaken the economic potential of Europe deliberately and systematically, drawing them into economic sanctions against Russia. They need a weak Europe, which, as a junior partner, will be dragged into a war that will weaken it, it will lose its sovereignty. This deliberate attack is aimed at subordinating the European currency to the US dollar, and, therefore, leaving the dollar an opportunity to form an unregulated world financial system within the framework of existing institutions [8].

Then the social system will remain the result of the purposeful activity of the illiberal model of globalization in the form in which it ensures the hegemony of the United States. This model is a mechanism that allows unproductively to concentrate huge values and power in the hands of the US financial capital. This model provides the redistribution of world profits in favor of the American economy, creating the foundations of social injustice and poverty and the ability to destroy entire nations and countries to protect their interests [9]. Highlighting the main conceptual approaches to the formation of US geopolitics leads to the understanding that, firstly, it is aggressive and in the long term will be aimed at "acts of sabotage" against the entire world economy to ensure its economic interests. Secondly, America will have to make great efforts to maintain its dominance in confronting several competing civilizational centers at once. In these conditions, for the United States, where an alliance of American corporations in the form of TNCs and TNBs has been formed, the only way out is to defend its economic ambitions through the use of the most aggressive forms of "cleansing" geopolitical opponents [5]. Since China is still a "tough nut to crack" for the United States, they have directed their attacks on Russia and Europe, pushing them against each other in the confrontation of economic interests through sanctions on sectors of the Russian economy. Potential targets for undermining the Russian economy are directed at six key sectors of the Russian economy: financial services, energy, metallurgy, mining, mechanical engineering and the defense industry (Barack Obama decree of March 20, 2014) [6]. It should be noted that these industries, which have come under US sanctions, are scrupulously calibrated and, it would seem, should deal a significant blow to the Russian economy (of course, all parties will suffer to some extent). But the most interesting thing is that we must thank the United States for pointing out the significant, on the one hand, and, on the other hand, the "weak link" of our economy and pay close attention to their subsequent development and transformation in the long term [4]. 


\section{Results and discussion}

The turbulence of the world economy, caused by all of the above reasons, puts before Russia the need for extraordinary macroeconomic decisions [6]. But so far, only the "rut effect" is realizing itself in the country - a connection between the past and the present - resistance to sanctions and "reindustrialization" with investing money in traditional industries and agriculture, large expensive investment projects and infrastructure development. In other words, the choice is limited by the established economic policy and traditional thinking of the business elite. The "rut effect" is not "inertia", it is a limitation of the possibilities of choice that exists "in the heads" in the present, based on the historical experience of the past. Facing the obstacle of the "rut effect" requires irreversible solutions: the formation of a new galaxy of professionals at all levels, whose mentality should become an understanding of the need to reconstruct economic policy and the institutional environment in its alternative form in relation to the existing one [8]. The motivation for overcoming the "rut effect" is the understanding of the objective need for Russia to retain its place in the world economy on the basis of new realities. We see that the President and the Government of the Russian Federation have begun to form such rules of the game that will favor production activities in the broadest sense of the word and rigidly pursue narrow self-serving motives at the expense of national interests. Unfortunately, the "rut effect" continues to operate [9]. But world experience shows that if we want to achieve real economic growth, financial stabilization and accelerated sustainable development at the level of modern trends in priority areas of social production, then it is necessary to understand that the richer the functional structure of the economy, the higher the likelihood that the goals will be achieved successfully. At the same time, the national model of development should be based on the intellectual potential of a new generation of professionals who are concerned with creating a national model of the economy, which is being formed under the auspices of the idea of economic strengthening of the economic potential of the Russian Federation [7].

In the context of new geopolitical risks, we must rely on Russia's inherent priorities to ensure long-term development trends of the country, and, first of all, on its resource, intellectual, and ideological potential of the younger generation, which understands the need to ensure interaction between private business and the state on a new basis. ... But the dependence of the Russian budget on oil and gas revenues is growing, and the contribution of other economic sectors to the formation of the budget is decreasing (the conclusion of the Accounts Chamber on the draft federal law "On Amendments to the Federal Law" On the Federal Budget for 2014 and for the Planning Period of 2015 and 2016 "), which indicates that "the state does not always do what it should", as J. Stiglitz asserts [8].

If we use a synergistic approach, then the optimality and increase in the degree of effectiveness of the impact of government decisions on the social system depends not on the strength of their pressure, but on the level of compliance of the direction of their action with the internal trends of evolution, both of the social system and the social environment. Therefore, not the most powerful, but small, properly organized - resonant - effects on this system and environment are, as a rule, more effective [6]. Especially at the stage of exacerbation of the external environment, contributing to the depressive development of the economy, when such powerful projects as Sochi, the Olympics, the Summit in the Far East have been completed, and business is less interested in investment activity. It is at this stage that the strategic sagacity of the state should manifest itself, its ability to see among the many possible paths and multidirectional fluctuations of the social environment leading fluctuations of a progressive nature. If the prompt adoption of optimal decisions and especially measures for their implementation is ensured, they will turn into attractors for structuring and ordering the updated economic system, which would correspond to the conditions of self-sufficiency of the Russian economy. 
In other words, for the Russian economy to get out of the state of balancing between stagnation and recession, there is no other alternative except for the resonant influence of the state in the direction of long-term development [9]. A targeted selection of investment projects should be aimed not only at countering sanctions in traditional industries, but also at the implementation of the "Industrial Revolution 4.0", which provides the latest production of the real sector of the economy in the long term, contributing to the solution of both internal risks and independence from the external market. Consequently, at the present stage, the selforganization of a market economy should be understood not in the absolute sense of its selfsuppression, but as a dynamic process of the action of factors of its spontaneous selforganization and factors of organizational management of the state. Modern research covers the influence of basic institutional structures - property and law enforcement to study the genesis of their influence on the nature of the relationship between the market and the state. The following significant conclusions can be pointed out based on economic analysis of cross-country data[10]:

- the higher the level of development of private property institutions (a guarantee against expropriation by the state and the ruling elites), the higher their positive impact on long-term economic growth, investment and the efficiency of financial markets;

- a more adequate implementation of the principles of private property is a necessary condition required for a more intensive development of the real sector of the economy;

- in countries where the judiciary has a relatively greater independence, private property rights are more protected and the conditions for intensive economic growth are provided;

- the success of legal norms and institutions is associated not only (in the case of the Russian economy - and not so much) with the choice of a particular system of legislation, but with the actual practice of law enforcement in the country;

- the more the "rut effect" is spread in society in the brains of the ruling elite, the less real opportunities remain for strengthening market institutions and competitive mechanisms.

\section{Conclusions}

Based on the above, we can say that in order to create interaction between the state and business in the Russian Federation in order to implement the new industrial revolution, it is necessary:

- creation of an institutional matrix that provides the conditions for an adequate set of formal institutions to solve urgent problems that establish the "rules of the game" to create the rights, duties and privileges of all to all [8];

- ensuring such a financial and monetary policy that will provide the production activity of the real sector of the economy with money. Why should KBs provide loans to businesses of all levels at the average world rate or at the inflation rate plus one percent;

- the definition of the fight against inflation as the fundamental basis of price growth should be reoriented from the main instrument as the money supply to the macroeconomic policy of the entire reproduction process with a priority on the development of promising long-term sectors of the real sector of the economy, as well as food production, energy and mechanical engineering, ensuring the economic independence of the Russian Federation [7];

- providing the basic processing sectors of the industry with financial flows, the absence of which increases the risks of a recessionary functioning of the entire economy;

- the formation of a clearly fixed form of the legal framework that ensures the taxation system in relation to all forms of ownership in all markets, including the elite;

- ensuring the composition of non-overlapping basic institutions that create the necessary conditions for interaction between the state and business, subject to the determination of the state's obligations to fulfill the protection of property rights and political rules in conditions of transparency of their financial performance [10]; 
- modification of market interaction to deepen the transformation process for the creation of digital and additive technologies that radically change the face of modern real production based on the generalization of national knowledge scattered in society in compliance with contractual agreements;

- provision of conditions for the creation of the real sector of the economy, as the second source of state revenue vital for the Russian economy for the development of public-private partnerships;

- creation of a special state fund for the development of domestic industry;

- ensure a systematic audit of the effectiveness of the financial system and monetary policy on the basis of how these institutions affect the development of the real sector of the economy, using and redistributing financial resources [8].

To solve these problems, a modern version of indicative planning is needed to determine the proportionality of allocated appropriations for solving internal problems in the short and long term, ensuring the interaction of the Government of the Russian Federation with industry associations of entrepreneurs, trade unions, various parties and consumers. This form of planning (successfully used in France) would help create a basis for overcoming sanctions and external threats, sustainable economic growth, contributing to solving the problems of social inequality through the creation of modern jobs with decent wages. This requires a system of indicative planning, which will be an impulse for the proportional development of the extractive and processing industries of the Russian economy [10]. The need for such a policy is associated with the possibility of using the investment potential of private businesses through the impulse influence of the state on the formation of drivers of modern production, providing an instrumental mechanism for the conditions of a "social lift" and human resources of the Russian economy. So, the modern form of globalization, which raised the issue of sectoral sanctions of the Russian Federation, carries threats to both financial and economic, and, consequently, social stability of Russia. Our dependence on the export of hydrocarbons and on world prices for them made it possible to impose economic sanctions on us, which finally led to an understanding of the need to reduce the dependence of the national economy and its financial system on unfavorable external factors. The question arises: what can help the Russian Federation find a way to enter a new vector of sustainable economic growth, ensuring the transformation of the bifurcation development of the Russian economy on the basis of the new "industrial revolution 4.0? If the strategic component of state policy shifts the center of gravity of interests of big business to the sphere of implementation of modern forms of the real economy based on the use of the national potential of national intellectual resources [11]. Then Russian entrepreneurship will occupy a specialized niche in the world market, based on the highly intellectual potential of our people, as well as on the absolute and relative comparative costs of production and natural conditions, where we have an obvious superiority at the world level, where we can secure ourselves a strong position. The principle of focusing on intellectual goods and services for the country's long-term development should become applicable to all areas of the Russian economy. An extraordinary competent macroeconomic policy will help the country survive the period of sanctions, from which the country will emerge stronger, ensuring the proportional development of all sectors of the economy, creating an economic margin of safety to withstand all external threats and create conditions for a multipolar world.

\section{References}

1. Yu.G. Kopylova, Alternative approaches to assessing the shadow economy in Russia and foreign states, 86 (2020)

2. I. V. Ilyin, Globalistics in the context of political processes, 125 (2019) 
3. V. L. Musatov, Russia in the web of globalization. M. East - West, 210 (2020)

4. V. G. Fedotova, Globalization and modernization. Globalistics: an international interdisciplinary encyclopedic dictionary, 176 (2018)

5. A. N. Chumakov, Metaphysics of globalization. Cultural and Civilizational Context, 95 (2020)

6. Campbell Scientific Inc Bowen Ratio system. Instruction manual. Logan, UT USA, 32 (2020).

7. W. A. Dugas, Micrometeorological and chamber measurements of CO2 flux from bare soil. Agricultural and Forest meteorology, 115 (2018)

8. W. A. Dugas, Bowen ratio CO2 measurements. Unpublished manuscript, 125 (2020)

9. Kh. Murtazova, M. Abdulkadirova, The Consumer Market in the New Economy, 2 (2021)

10. F. Dakhaeva, Large Cities in the Process of New Industrialization, 6 (2020)

11. F. Dakhaeva, A. Amirova, Socially-oriented economy as part of the macroeconomic development system, 5 (2020) 